\title{
DISCIPLINARY DIFFERENCES AND STUDENTS' LEARNING PREFERENCES
}

\author{
Jim Ellis ${ }^{1}$ \\ ${ }^{1}$ Head of Technology Enhanced Learning, Learning and Teaching Innovation, The Open University, UK
}

\begin{abstract}
The provision of education at scale with finite resources almost inevitably means there will be an abundance of common approaches that aim to provide best-fit solutions for subject matter, teachers and learners. This paper considers differences in the characteristics of subject matter across academic disciplines, and how those differences affect not only on how subjects are best taught and assessed, but also the nature of those who are drawn to different fields, either as students or teachers. For the growing number of distance or online learners (purely, or as part of a blend), technology is having an increasing effect on their learning experiences, and evidence is presented to show some notable differences in learner preferences across the disciplines, such that institutions should consider if the pedagogic penalties may sometimes outweigh the apparent benefits and efficiencies of blanket ed-tech solutions.
\end{abstract}

Keywords: Disciplinary differences, student preferences, educational technology, learning design, online learning - ***

\section{INTRODUCTION}

The maxim 'one size does not fit all' is preached far more than it is practiced in education and, whilst unfortunate, this is not entirely surprising. Bespoke personalized learning remains a worthy aspiration but practicalities such as time and competing individual needs within a group often get in the way, even for the most experienced, intuitive and willing teacher. Online learning might appear to offer greater potential for a more adaptive approach, based on analyses of student preferences and performance, but early pseudointelligent solutions are either too simplistic or expensively complex and do not yet deliver at scale on their claimed potential across all subject areas. The reality is that most online learning activities and content are of a good standard, but are prepared well in advance for a best-fit audience profile. Although many VLEs/LMSs make it possible to build-in simple options, conditional branching and elective material, this all adds to an organization's design, production, testing and support costs, and may risk overloading or even confusing some students.

Many distance learning providers, especially those serving broad or open demographic profiles, invest considerable effort into collecting survey and system information to determine the preferences, behaviours and performance of their learners. However, it can often be the case that this is analyzed and design decisions are made at an institutional level [1], whereas Pektaş and Gürel [2] believe there is evidence to suggest, "each discipline has unique characteristics that may have important implications for educators and educational system developers" (p31).

These disciplinary differences are important for designers of distance learning because they can often be fairly easily accommodated in the initial development of modules and courses. This is in contrast to some individual differences that we can establish when students enrol - e.g. age [3], gender [4], qualifications/grades [5] - but do little about once activities and materials have been prepared, and others - e.g. reading ability [6], working memory capacity [7], extroversion and introversion [8] - which we can ascertain through testing but probably do even less to accommodate at a distance. Hence, making design adjustments for known disciplinary differences can represent a pedagogic quick-win for both institutions and their students.

This paper considers the nature of different academic disciplines, the attributes of people who are drawn to each and the inevitable impact on how they are taught and assessed before then turning to students and their own preferences for, and perceptions of, their learning experience, including the impact of increasing usage of online learning and educational technologies.

\section{LITERATURE REVIEW}

\subsection{Discipline Characteristics}

Biglan [9] recognised that universities were organized into academic departments and that the structure, inhabitants and methods of teaching and research within each one tended to vary according to discipline. This led him to conduct research into the essential differences in attributes of academic disciplines, seeking to develop a framework of subject matter characteristics. Based on categorization of 36 subject areas made by 222 scholars at a large US university and a smaller liberal arts college, he concluded that: "Three dimensions appear to characterize the subject matter of academic areas in most institutions. The dimensions involve (a) the degree to which a paradigm exists, (b) the degree of concern with application, and (c) concern with life systems. These ... dimensions may provide a useful framework for studying the cognitive style of scholars in different areas" 
(p202). He further explains that, “By 'paradigm' Kuhn [10] refers to a body of theory which is subscribed to by all members of the field" (p201).

Table -1: Hard/Soft and Pure/Applied Characteristics

\begin{tabular}{|c|c|c|}
\hline & Hard & Soft \\
\hline \multirow[t]{2}{*}{ Pure } & $\begin{array}{l}\text { Knowledge is } \\
\text { cumulative, atomistic } \\
\text { (crystalline/tree-like); } \\
\text { concerned with } \\
\text { universals, quantities, } \\
\text { simplification; } \\
\text { impersonal, value- } \\
\text { free; clear criteria for } \\
\text { knowledge } \\
\text { verification } \\
\text { obsolescence; and } \\
\text { consensus } \\
\text { significant questions } \\
\text { to address; results in } \\
\text { discovery/explanation }\end{array}$ & $\begin{array}{l}\text { Knowledge is } \\
\text { reiterative; holistic } \\
\text { (organic/river-like); } \\
\text { concerned with } \\
\text { particulars, qualities, } \\
\text { complication; } \\
\text { personal, value-laden; } \\
\text { dispute over criteria } \\
\text { for knowledge } \\
\text { verification and } \\
\text { obsolescence; lack of } \\
\text { consensus over } \\
\text { significant questions } \\
\text { to address; results in } \\
\text { understanding or } \\
\text { interpretation }\end{array}$ \\
\hline & $\begin{array}{l}\text { Cultureis competitive, } \\
\text { gregarious; politically } \\
\text { well-organized; high } \\
\text { publication rate; task- } \\
\text { oriented }\end{array}$ & $\begin{array}{lr}\text { Culture } & \text { is } \\
\text { individualistic, } & \\
\text { plurastic; loosely } \\
\text { structured; low } \\
\text { publication rate; } \\
\text { person oriented }\end{array}$ \\
\hline \multirow[t]{2}{*}{ Applied } & $\begin{array}{l}\text { Knowledge is } \\
\text { purposive; pragmatic } \\
\text { (know-how via hard } \\
\text { knowledge); } \\
\text { concerned with } \\
\text { mastery of physical } \\
\text { environment; applies } \\
\text { heuristic approaches; } \\
\text { uses both qualitative } \\
\text { and quantitative } \\
\text { approaches; criteria } \\
\text { for judgement are } \\
\text { purposive, functional; } \\
\text { results in } \\
\text { products/techniques }\end{array}$ & $\begin{array}{l}\text { Knowledge } \\
\text { functional; utilitarian } \\
\text { (know-how via soft } \\
\text { knowledge); } \\
\text { concerned with } \\
\text { enhancement of } \\
\text { [semi-] professional } \\
\text { practice; uses case } \\
\text { studies and case law } \\
\text { to a large extent; } \\
\text { results } \\
\text { protocols/procedures }\end{array}$ \\
\hline & $\begin{array}{l}\text { Culture is } \\
\text { entrepreneurial, } \\
\text { cosmopolitan; } \\
\text { dominated by } \\
\text { professional values; } \\
\text { patents substitutable } \\
\text { for publications; role } \\
\text { oriented }\end{array}$ & $\begin{array}{l}\text { Culture is outward- } \\
\text { looking; uncertain in } \\
\text { status; dominated by } \\
\text { intellectual fashions; } \\
\text { publication rates } \\
\text { reduced } \\
\text { consultances; power- } \\
\text { oriented }\end{array}$ \\
\hline
\end{tabular}

Most subsequent related research has adopted these broad categories - more succinctly referred to as Hard/Soft (e.g. engineering-nursing) and Pure/Applied (e.g. philosophynursing) - although the majority of researchers have dropped the Life/Non-Life axis as being less pertinent, whilst others have used different terminology such as Kolb's Reflective/Active and Abstract/Concrete [11]. Becher [12] suggests that distinctions between disciplines are potentially adversarial, describing them as "academic tribes, each with their own set of intellectual values and their own patch of cognitive territory" (p153). He explains the characteristics of the four quadrants both in terms of the nature of the knowledge involved and predominant culture of each discipline, as given in Table 1.

Nelson Laird et al [13] believe there to be little element of chance in the field of study any individual is drawn to. Rather, it tends to reflect the personality traits encapsulated in the cultural descriptions in Table 1 and, "Consequently, a discipline or field usually reflects the values and norms held by its constituent individuals or dominant groups" (p472). Becher [14] refers to socialization into a discipline, which he believes starts in graduate training and Lattuca and Stark [15] observe, "to be accepted into the disciplinary community, an individual typically must demonstrate both technical competence in the discipline and loyalty to the collegial group and its norms" (p320).

Table 2 shows the assignment of specific academic subjects to Hard/Soft and Pure/Applied quadrants, based on Biglan's original work [16], supplemented by that of Becher [17], Nelson Laird et al [13] and White and Liccardi [18], plus some more recent categorization of UK Open University distance learning subject areas by Coughlan and Perryman [19].Thiscategorization process is described by Coughlan and Perryman [19] as "neither uniform nor exact" (p16) because of the different emphasis or perspectives on a subject that may be taken by departments, curricular requirements or individual academics. For example, they note that "White and Licardi [18] place Linguistics in three different categories: Hard-Pure, Soft-Pure, and SoftApplied" (p16), and Neumann et al [20] agree that "Linguistics can be seen in large part to have moved from soft pure to hard pure as computer-related methods have gained ascendancy” (p407).

\subsection{Academic Approaches to Teaching}

On the basis that academics were once students and students, according to Hativa and Birenbaum [21], "tend to study in academic disciplines that suit their approach to learning and personal characteristics" (p213), it is reasonable to assume that methods of teaching will reflect the characteristics given in Table 1; hence, Neumann's observation [22]: "It is not surprising to learn that academics in the humanities spend the most time on lectures, seminars and tutorials, that academics in the natural sciences, technology and medicine spend most time on laboratory teaching, exercises and field trips, and that academics in technological disciplines spend much time on lectures and little on seminars" (p136).

In Hard topics such as the Physical Sciences, the skills to be acquired may be procedural or related to problem-solving, meaning there is often a clear 'correct solution' and accepted routes to achieving it. Hence, there may be common agreement over how best to conceptualize and understand such topics; it may also be the case (or perception) that the need for student-centred learning or 
reflection is limited [23]. Lectures, workshops, laboratory work and problem classes are commonplace [20] and there may be a greater emphasis placed by academics in Hard disciplines on memorization and application of course concepts [24], on student career preparation and on emphasize of cognitive goals such as learning facts, principles and concepts [25].

Table -2: Hard/Soft and Pure/Applied Characteristics

\begin{tabular}{|c|c|c|}
\hline & Hard & Soft \\
\hline Pure & $\begin{array}{l}\text { Astronomy } \\
\text { Biology } \\
\text { Bioscience } \\
\text { Botany } \\
\text { Chemistry } \\
\text { Earth/Environmental } \\
\text { Sciences } \\
\text { Geology } \\
\text { Life Sciences } \\
\text { Linguistics } \\
\text { Mathematics } \\
\text { Meteorology } \\
\text { Operational Research } \\
\text { Physics } \\
\text { Physiology } \\
\text { Science } \\
\text { Statistics } \\
\text { Zoology }\end{array}$ & $\begin{array}{l}\text { Anthropology } \\
\text { Archaeology } \\
\text { Art } \\
\text { Classical Studies } \\
\text { Criminology } \\
\text { Drama } \\
\text { Economics } \\
\text { English } \\
\text { Geography } \\
\text { History } \\
\text { International Studies } \\
\text { Languages/Linguistics } \\
\text { Literature } \\
\text { Music } \\
\text { Philosophy } \\
\text { Politics } \\
\text { Psychology } \\
\text { Religion/Theology } \\
\text { Social Sciences } \\
\text { Sociology }\end{array}$ \\
\hline Applied & $\begin{array}{l}\text { Aeronautical } \\
\text { Engineering } \\
\text { Agriculture } \\
\text { Behavioural Science } \\
\text { Built Environment } \\
\text { Chemical } \\
\text { Engineering } \\
\text { Civil Engineering } \\
\text { Construction } \\
\text { Computer Science } \\
\text { Dentistry } \\
\text { Design } \\
\text { Electrical/Electronic } \\
\text { Engineering } \\
\text { General Engineering } \\
\text { Health Science and } \\
\text { Practice } \\
\text { Horticulture } \\
\text { Mech Engineering } \\
\text { Medicine } \\
\text { Pharmacy } \\
\text { Psychology } \\
\text { Software Engineering } \\
\text { Technology } \\
\text { Veterinary Medicine }\end{array}$ & $\begin{array}{l}\text { Accountancy } \\
\text { Architecture } \\
\text { Art/Design } \\
\text { Business } \\
\text { Communications } \\
\text { Dance } \\
\text { Drama } \\
\text { Economics } \\
\text { Education/Teaching } \\
\text { Finance } \\
\text { Health \& Social Care } \\
\text { Hospitality, Leisure } \\
\text { and Tourism } \\
\text { Journalism } \\
\text { Languages/Linguistics } \\
\text { Law } \\
\text { Management } \\
\text { Marketing } \\
\text { Media } \\
\text { Music } \\
\text { Nursing } \\
\text { Sport } \\
\text { Urban Planning } \\
\text { Youth Justice }\end{array}$ \\
\hline
\end{tabular}

In contrast, Soft topics such as the Arts and Humanities are more likely to require students to develop a broad general knowledge to support skills for appreciation, critical analysis, synthesis and debate of alternative perspectives, plus a focus on reflection; hence, the teaching approach may need to vary according to circumstances [13, 23, 26]. Academics in Soft disciplines are also more likely to place greater importance on student character development, internal motivation, high expectations, student-faculty contact and intellectual growth [22, 25, 27]. Class sizes tend to be smaller with an emphasis on open-ended discussion and debate through tutorials and seminars [28].

Differences in emphasis between the teaching of Hard and Soft topics are confirmed by a UKES survey [29] which showed $35.9 \%$ of STEM students analysing numerical information "very much" compared to just $8.0 \%$ of those in the Arts and Humanities. In contrast, $41.4 \%$ of Arts and Humanities students reported evaluating or judging a point of view, decision, or information source "very often" compared to just $18.7 \%$ of STEM students, and the situation was echoed for 'connecting your learning to societal problems or issues' (23.7\% Arts and Humanities vs 9.2\% STEM).

Whereas knowledge acquisition is significant in Pure disciplines, the Applied disciplines place much greater emphasis on application and integration of that knowledge [24] and this often leads to a need to gain practical experience. For Hard-Applied fields, the use of real or simulated environments allows learners to gain experience which enhances knowledge acquisition. In contrast, learners in Soft-Applied fields are more likely to need to have already established a reasonable base of knowledge before they can get the most from any practical experience [20]. DeFillippi and Milter [30] recommend employing instructional strategies that are focused on solving problems in order to promote Soft-Applied skills transfer into the workplace, and Neumann et al [20] note that, "A unique feature of soft applied fields is the tendency to include the contributions of experienced practitioners as a significant component in the teaching process" (p412). However, this can often be hard to communicate directly [31] and might be better learned through individual or group activities [32], an approach supported by evidence from Kember and Leung [26] showing that Business students reported greater amounts of 'working together' than those in other humanities subjects and the sciences.

\subsection{Assessment}

Methods of assessment and question types favoured by teachers tend to divide along disciplinary lines. Hard topics often favour objective questions that test recall of knowledge and procedures, with Soft disciplines more likely to use questions that require students to demonstrate analysis and synthesis of material [24, 25]. This might suggest that Hard topics would make greater use of multiple-choice questions and Smith et al (2008) report this to be the case, although Warren Piper et al [33] found the division to fall along Pure/Applied lines, with multiplechoice more prevalent in Applied fields. This reflects more of an emphasis on knowledge acquisition in Pure disciplines than Applied, with the latter focusing more on knowledge application and integration. Neumann et al [20] report 
practical work, peer- and self-assessment to be common in Soft-Applied fields, with essays, short answer questions and project reports more widely used in Soft-Pure fields. They also identify the different ways in which knowledge is constructed, with Hard topics such as STEM, "more likely to utilize assessment tasks that emphasize the acquisition of knowledge blocks in a cumulative process, whereas in the humanities and social sciences ... assessment tasks emphasize knowledge application and integration, usually in essay or explanatory form" (p408).

Written examinations are used extensively at undergraduate level across all fields, often supplemented by oral presentations in the humanities, continuous assessment for Soft Pure fields, reports on practical work in Hard-Pure fields and assessment of practice for Soft-Applied students. Probably because there is greater accord over 'right or wrong' in Hard fields, these - and especially mathematics see less use of marking guidelines or double marking, but greater norm-referencing of grade boundaries; and where marking and grading guidelines are used in Soft fields, they may be ambiguous because it can be difficult to describe requirements in explicit and precise terms [20,33].

\subsection{Student Perceptions of Learning}

It is likely that, unless prompted, students will not think too hard about the specific methods by which they are being taught, but we know from our own experiences as learners that they will be far more cognizant of how stimulating, relevant and effective they consider the learning experience to be. But is it the case that some topics are inherently less inspiring than others; and does student-discipline matching again come into play (e.g. will students drawn to study history tend to find history interesting and maths dull, and vice versa); or can an excellent teacher make virtually any topic enthralling? Almost inevitably, student opinions of a topic will be influenced by its teachers, and Kember and Leung [26] report a fairly consistent picture emerging from meta-studies of face-to-face delivery, with students of the arts, humanities and social sciences rating their teachers more highly than those in science and engineering. Neumann et al [20] echoed this, finding that, "student [questionnaire] ratings have been shown to vary systematically across knowledge fields, with soft disciplines being accorded the consistently highest average scores and hard ones the lowest" ( $\mathrm{p} 415)$. There also appears to be a relationship between those findings and the amount of staffstudent interaction time, reported by Neves [34] as dividing along disciplinary lines, ranging from creative arts (44\%) and education (39\%) down to maths $(23 \%)$ and veterinary science $(17 \%)$.

Lueddeke [35] reported differences in the balance of student- and teacher-centeredness, with Soft disciplines tending to favor a predominantly student-centred approach whereas Hard disciplines were more teacher-centred. Hativa and Birenbaum [21] found similar Hard/Soft distinctions between engineering and education undergraduates but, when prompted to express a preference for teaching methods, student responses were the opposite of those the researchers expected. Education students, who were exposed to many more student-centred activities than lectures, expressed a preference for "the clear and interesting instructor, with his/her teacher-centred orientation" (p228). In contrast, engineering students, who mostly receive teacher-centred sessions, instead yearned for the "providing instructor" who facilitates cooperation and help-seeking in a supportive learning climate. Engineering students were also required to adopt many self-regulated learning approaches - e.g. undertaking projects and solving problems on their own - and yet a statistically significant lower number expressed a preference for this compared to students of education.

Advances in technologies provide teachers and students, especially those in distance education, with both opportunities and threats, probably in equal measure. And, just as with face-to-face, Arbaugh et al [36] note that, "disciplinary effects may have a strong effect on student satisfaction with online learning" (p39). Selwyn [37] investigated the "messy realities of student engagements with digital technology" by soliciting negative experiences under four headings: Distraction (diverting attention from study; e.g. social media); Disruption (technology failing to function; e.g. networks, projectors); Difficulty (technologies made life harder; e.g. electronic reading and note-taking); and Detriment (lower quality learning; e.g. 'death by PowerPoint'). The disciplinary areas of students most and least affected are shown in Table 3.

Table -3: Students' Negative Technology Experiences

\begin{tabular}{|l|l|l|}
\hline Experience & Most Affected & Least Affected \\
\hline Distraction & $\begin{array}{l}\text { Humanities and } \\
\text { languages(29.2\%) }\end{array}$ & $\begin{array}{l}\text { Education } \\
(14.8 \%)\end{array}$ \\
\hline Disruption & $\begin{array}{l}\text { Education } \\
(34.6 \%)\end{array}$ & $\begin{array}{l}\text { Creative arts and } \\
\text { design (16.7\%) }\end{array}$ \\
\hline Difficulty & $\begin{array}{l}\text { Medicine } \\
(29.2 \%)\end{array}$ & $\begin{array}{l}\text { Law } \\
(17.2 \%)\end{array}$ \\
\hline Detriment & $\begin{array}{l}\text { Social sciences } \\
(26.5 \%)\end{array}$ & $\begin{array}{l}\text { Law } \\
(13.9 \%)\end{array}$ \\
\hline
\end{tabular}

Lam et al [38] questioned 1,400 undergraduate students about technology use, finding that those in Applied disciplines were more ICT-confident than their Pure counterparts and tended to have more experience in using technology both for teaching and learning, and self-study. However, "the difference between the Soft and Hard disciplines was not as clear cut" (p119). This supports earlier research by Smith et al [39] who found that e-mail, messaging, Dropbox and electronic document use was significantly higher in Applied courses than Pure, although online testing and question pools/banks were most used in Hard Pure courses. Smith et al [39] also refer to Moore's [40] notion of Transactional Distance (TD) - the physical, temporal and perceived psychological space between teacher and student - suggesting that this is likely to be more significant in Hard or Pure disciplines than Soft or Applied, but that it might be reduced, "by increasing the dialogue, through use of teleconferencing, online synchronous meetings, email, or even well-structured print 
materials" (p154). Hammond and Bennett [23] also considered the use of online discussions, noting that they featured, "very frequently as an activity in the Humanities, less so in Psychology and even less in the Physical Sciences" (p59).

Online discussion and communities can offer considerable benefits in overcoming the loneliness of the long distance learner, but the debate over 'lurkers' - those who may read posts but are reluctant to contribute themselves [41] - and whether contributions should be mandatory or somehow assessed, continues. Gorsky et al [42] analyzed optional forum use by students on 25 sciences and 25 humanities university courses over a three-week period, finding twice the participation rate in the sciences (12.86\%) compared to the humanities $(6.17 \%)$. However, these findings are not typical: Finnegan et al [43] investigated forum use over an academic year by students in the fields of English, Social Sciences and STEM. Of those who completed $(\mathrm{N}=1,862)$, social science students read the most discussion posts (466), composed the most new posts (10) and made the most follow-up posts (34.5). English students were similar (but made more original posts: 12.6) but STEM students showed least engagement (192, 5.5 and 12.3 posts respectively), leading the researchers to conclude that, "a 'one size fits all' approach to best practice in online courses may be counterproductive to student success" (p52). Hammond and Bennett [23] also found considerably greater engagement in online discussion by humanities students than those in psychology or physical sciences.

But moving beyond social media and forum use, what of the broader view of online teaching and assessment? In an analysis of data from over 13,000 students in 167 undergraduate courses over a six-year period, Hornik et al [1] investigated which types of course are best suited for delivery online. They found that student grades and withdrawal rates are significantly better "for courses with high paradigm development" (p35); i.e. Hard (Pure or Applied) topics such as STEM than for low paradigm courses such as humanities. This was particularly the case for advanced or higher-level modules, where student satisfaction was also seen to be better.

White \& Licardi [18] conducted a survey of student online learning preferences and, as Table 4 shows, this revealed some stark contrasts between disciplines. For example, many Soft-Pure students wanted to access live or recorded lectures from home but $86 \%$ of Soft-Applied students did not wish to study in this way; and $98 \%$ of Hard-Applied students wanted more online tests but, for Hard-Pure students, this fell to just $15 \%$. These latter preferences appear mismatched to the actuality reported by Lam et al [38] thus: "...Hard/Pure subjects in science tended to incorporate more online assessments in comparison with other subjects" (p112). However, Conole et al [44] suggested, 'The more 'qualitative', 'textual' or 'visual' the subject, the less appropriate e-assessment (in the form of binary-type multiple choice questions) was deemed to be" (p521). If we take 'qualitative' to infer less paradigmatic, 'textual' as discursive and 'visual' as having obvious imagistic components (such as the Arts), then these are all Soft attributes that fit well with the student preferences in Table 4 which show a much reducedinclination (than Hard) for e-assessment.

Table -4: Students' Online Learning Preferences

\begin{tabular}{|c|c|c|}
\hline & Hard & Soft \\
\hline Pure & 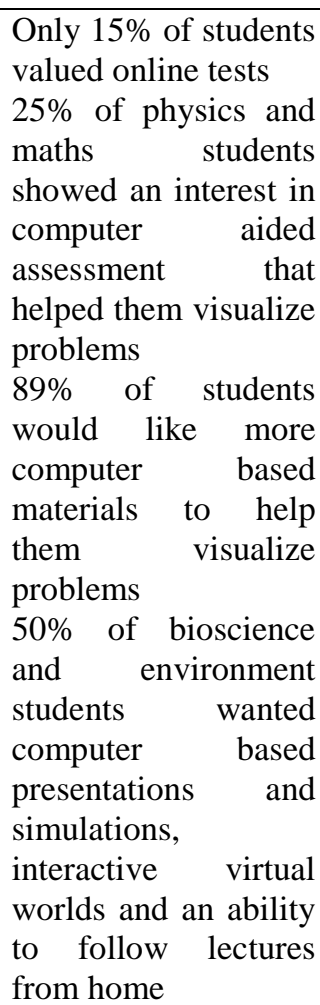 & $\begin{array}{l}\text { Students } \\
\text { online discussion, } \\
\text { amongst themselves } \\
\text { and with students in } \\
\text { other universities } \\
\text { Students wanted to } \\
\text { receive lectures and } \\
\text { watch documentaries } \\
\text { from home } \\
\text { Economics students } \\
\text { found simulated } \\
\text { environments } \\
\text { beneficial } \\
\text { English students } \\
\text { found online materials } \\
\text { very useful } \\
\text { 30\% welcomed online } \\
\text { practice tests }\end{array}$ \\
\hline Applied & $\begin{array}{l}\text { Students generally } \\
\text { found the VLE useful } \\
\text { as a container for } \\
\text { online testing } \\
98 \% \text { would like more } \\
\text { online tests } \\
26 \% \text { wanted more } \\
\text { online materials } \\
\text { General desire for } \\
\text { more interactive tests } \\
\text { in class so students } \\
\text { and teachers can } \\
\text { check understanding } \\
76 \% \text { of medical } \\
\text { students welcomed } \\
\text { online learning, } \\
\text { computer based } \\
\text { presentations and } \\
\text { testing a }\end{array}$ & $\begin{array}{l}100 \% \text { of students } \\
\text { would like computer } \\
\text { based simulations, } \\
\text { especially role playing } \\
\text { games } \\
86 \% \text { did not want } \\
\text { online lectures as they } \\
\text { prefer live discussion } \\
\text { (little enthusiasm for } \\
\text { online discussion) } \\
89 \% \text { of linguistics } \\
\text { students wanted more } \\
\text { online materials } \\
\text { Law students wanted } \\
\text { more online role } \\
\text { playing games }\end{array}$ \\
\hline
\end{tabular}

White \& Licardi's study [18] should be of particular interest to designers of online learning, although it is based on a relatively small sample size $(\mathrm{N}=286)$ and is now a relatively elderly barometer for online user attitudes, having been published five or so years ahead of the advent of Instagram, Snapchat, Google+ and the first iPads. It has also been criticized by Smith et al (2008) because, "In asking on- 
campus students about e-learning techniques, no distinction was made between e-learning elements of hybrid, blended, web-enhanced courses, versus fully online courses" (p66).

\section{CONCLUSION}

There is fairly widespread accord amongst researchers over the key differences in nature between academic disciplines, and those differences have a corresponding effect not only on how subjects are taught and assessed, but also the characteristics of those who are drawn to different fields, either as students or teachers. In essence, Hard topics are underpinned by a 'paradigm' - a body of theory accepted by all members of the field - whilst Soft topics are more subjective and interpretive; Pure topics tend towards the theoretical, with their Applied counterparts based more on how that theoretical knowledge is integrated and applied. Placing individual degree subjects into any one quadrant is not an exact science because departments, curricular requirements or individual academics may take different emphases or perspectives on a subject - linguistics and art \& design being just two examples of those which are often placed in different categories.

Students are likely to be less concerned with pedagogic underpinnings and much more conscious of how stimulating, relevant and effective they consider their learning experience to be and, when surveyed, their assessment of these criteria is likely to be heavily influenced by staff contact time and the individual characteristics of their teacher(s) or authors of materials. Student experiences - especially those of distance learners - are also now much more likely to be affected by imposed or elective use of technologies, and a study by White and Liccardi [18] provided a valuable insight into differing attitudes and requirements across disciplines.

The White and Liccardi study was relatively small and is now, in ed-tech terms, quite dated. Technologies, their use for social, work or study purposes, and levels of confidence and acceptance amongst students and teachers have inevitably moved on - and it would be helpful to get an updated and robust measure of this through further research.

Having established current learner preferences, it would also be helpful to gauge the realities of different approaches to teaching; and my hypotheses would be that there is considerable distinction in face-to-face approaches across disciplines and reasonable distinction in distance or online education but, where technologies are applied as part of institutional initiatives (e.g. projected PowerPoint, recorded lectures) or systems (e.g. VLE-hosted discussions or practice tests), we will see much more of a blanket approach. If true, this conflicts with the one message that has been abundantly clear throughout this paper: the evident differences in the subject matter, culture and preferences of students across different disciplines means that an organizational 'one size fits all' approach is far from being the most effective way forward for the design and implementation of both learning and educational technologies.

\section{REFERENCES}

[1]. Hornik S, Sanders C, Li Y, Moskal P \& Dziuban C (2008). 'The impact of paradigm development and course level on performance in technology-mediated learning environments', Informing Science, 11, pp35-58

[2]. Pektaş S \& Gürel M (2014). 'Blended learning in design education: An analysis of students' experiences within the disciplinary differences framework', Australasian Journal of Educational Technology, 30(1), pp31-44

[3]. Hancock H, Fisk A \& Rogers W (2005). 'Comprehending product warning information: age-related effects of memory, inferencing, and knowledge', Human Factors, 47(2), pp219-234

[4]. Price L (2006). 'Gender differences and similarities in online courses: challenging stereotypical views of women', Journal of Computer Assisted Learning, 22, pp349-359

[5]. Aidoo-Buameh J \& Ayagre P (2013). 'The Effect of Entry Grades on Academic Performance of University Accounting Students: A case of Undergraduates of Central University College', Research Journal of Finance and Accounting, 4(7), pp198-206

[6]. Schnotz W \& Bannert M (2003). 'Construction and interference in learning from multiple representation', Learning and Instruction, 13(2), pp141-156

[7]. Sanchez C \& Wiley J (2006). 'An examination of the seductive details effect in terms of working memory capacity', Memory \& Cognition, 34(2), pp344-355

[8]. Offir B, Bezalel R \& Barth I (2007). Introverts, Extroverts, and Achievement in a Distance Learning Environment, The American Journal of Distance Education, 21(1), pp3-19

[9]. Biglan A (1973a). 'The Characteristics of Subject Matter in Different Academic Areas', Journal of Applied Psychology, 57(3), pp195-203

[10]. Kuhn T (1970). The structure of scientific revolutions (2nd Ed), Chicago: University of Chicago Press

[11]. Kolb D (1981). 'Learning styles and disciplinary differences', in Chickering A (Ed), The Modern American College, San Francisco, Jossey Bass

[12]. Becher T (1994). 'The Significance of Disciplinary Differences', Studies in Higher Education, 19(2), pp151-161 [13]. Nelson Laird T, Shoup R, Kuh G \& Schwarz M (2008). 'The Effects of Discipline on Deep Approaches to Student Learning and College Outcomes', Research into Higher Education, 49, pp469-494

[14]. Becher T (1987). 'The Disciplinary Shaping of the Profession', in Clark B (Ed) The Academic Profession: National, Disciplinary and Institutional Settings, Berkeley: University of California Press

[15]. Lattuca L \& Stark J (1995). 'Modifying the Major: Discretionary Thoughts from Ten Disciplines', The Review of Higher Education, 18(3), pp315-344

[16]. Biglan A (1973b). 'Relationships between subject matter characteristics and the structure and output of university departments', Journal of Applied Psychology, 57(3), pp204-213

[17]. Becher T (1989). Academic tribes and Territories, Milton Keynes: Open University Press

[18]. White S \& Liccardi I (2006). 'Harnessing Insight into Disciplinary Differences to Refine e-learning Design', paper 
presented at 36th ASEE/IEEE Frontiers in Education Conference, San Diego

[19]. Coughlan T \& Perryman L-a (2011). 'Something for everyone? The different approaches of academic disciplines to Open Educational Resources and the effect on widening participation', Journal of Open, Flexible and Distance Learning, 15(2) pp11-27

[20]. Neumann R, Parry S \& Becher T (2002). 'Teaching and Learning in Their Disciplinary Contexts: A Conceptual Analysis', Studies In Higher Education, 27, pp405-418

[21]. Hativa N \& Birenbaum M (2000). 'Who prefers what? Disciplinary differences in students' preferred approaches to teaching and learning styles', Research in Higher Education, 41(2), pp209-236

[22]. Neumann R (2001). 'Disciplinary Differences and University Teaching', Studies in Higher Education, 26 (2), pp135-146

[23]. Hammond N \& Bennett C (2002). 'Discipline differences in role and use of ICT to support group-based learning', Journal of Computer Assisted Learning, 18, pp5563

[24]. Smart J \& Ethington C (1995). 'Disciplinary and institutional differences in undergraduate education goals', in Hativa $\mathrm{N} \&$ Marincovich $\mathrm{M}$ (Eds) Disciplinary Differences in Teaching and Learning: implications for practice, San Francisco: Jossey-Bass

[25]. Braxton J (1995). 'Disciplines with an affinity for the improvement of undergraduate education, in Hativa $\mathrm{N}$ \& Marincovich M (Eds) Disciplinary Differences in Teaching and Learning: implications for practice, San Francisco: Jossey-Bass

[26]. Kember D \& Leung D (2011). 'Disciplinary Differences in Student Ratings of Teaching Quality', Research in Higher Education, 52, pp278-299

[27]. Ylijoki O (2000). 'Disciplinary cultures and the moral order of studying - a case study of four Finnish university departments' Higher Education, 39, pp339-362

[28]. Parry S \& Dunn L (2000). 'Benchmarking as a meaning approach to learning in online settings', Studies in Continuing Education, 22, pp219-234

[29]. Buckley A (2014). UK Engagement Survey 2014: The second pilot year, York: The Higher Education Academy

[30]. DeFillippi R \& Milter R (2009). 'Problem-based and project-based learning approaches: Applying knowledge to authentic situations', in Armstrong $\mathrm{S} \&$ Fukami $\mathrm{C}$ (Eds) The SAGE Handbook of Management Learning, Education, and Development, London: Sage.

[31]. Anderson J (2000). Learning and Memory, New York: Wiley

[32]. Schank R (1996). 'Goal-based scenarios: Case-based reasoning meets learning by doing', in Leake D (Ed) CaseBased Reasoning: Experiences, Lessons and Future Directions, Boston: MIT Press

[33]. Warren Piper D, Nulty D \& O’Grady G (1996). Examination Practices and Procedures in Australian Universities, Canberra: Department of Employment, Education, Training and Youth Affairs

[34]. Neves J (2016). Student Engagement and Skills Development: The UK Engagement Survey 2016, York: The Higher Education Academy
[35]. Lueddeke G (2003). 'Professionalising teaching practice in higher education: a study of disciplinary variation and 'teaching-scholarship', Studies in Higher Education, 28, pp213-228

[36]. Arbaugh J, Bangert A \& Cleveland-Innes M (2010). 'Subject matter effects and the Community of Inquiry (CoI) framework: An exploratory study', Internet and Higher Education, 13, pp37-44

[37]. Selwyn N (2016). 'Digital downsides: exploring university students' negative engagements with digital technology', Teaching in Higher Education, http://dx.doi.org/10.1080/13562517.2016.1213229

[Accessed 11 Aug 16]

[38]. Lam P, McNaught C, Lee J \& Chan M (2014). 'Disciplinary difference in students' use of technology, experience in using eLearning strategies and perceptions towards eLearning', Computers \& Education, 73, pp111120

[39]. Smith G, Heindel A, \& Torres-Ayala A (2008). 'eLearning commodity or community: Disciplinary differences between online courses', Internet and Higher Education, 11, pp152-159

[40]. Moore M (1997). 'Theory of transactional distance', in Keegan D (Ed) Theoretical Principles of Distance Education, New York: Routledge

\section{BIOGRAPHY}

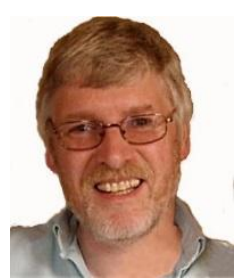

Dr Jim Ellis (jim.ellis@open.ac.uk) is Head of Technology Enhanced Learning at the UK Open University. He leads a team of TEL designers who support the design, development and evaluation of new OU modules. 